\title{
Wyoming Big Sagebrush Recovery and Understory Response With Tebuthiuron Control
}

\author{
Kirk C. McDaniel, ${ }^{1}$ L. Allen Torell, ${ }^{2}$ and Carlos G. Ochoa ${ }^{3}$ \\ Authors are ${ }^{1}$ Professor, Department of Animal and Range Sciences, Box 3-I, New Mexico State University, \\ Las Cruces, NM 88003; and ${ }^{2}$ Professor and ${ }^{3}$ former graduate research assistant, Department of Agricultural Economics \\ and Agricultural Business, New Mexico State University, Las Cruces, NM 88003.
}

\begin{abstract}
Field data collected over a 20-year period at 8 sites in northwestern New Mexico was used to determine Wyoming big sagebrush (Artemisia tridentata ssp. wyomingensis Beetle and Young) recovery following control with tebuthiuron (N-[5-(1,1dimethylethyl)-1,3,4-thiadiazol-2-yl]-N-N'-dimethylurea) and to relate understory perennial grass yield to overstory canopy cover. Tebuthiuron killed between $80 \%$ and $95 \%$ of mature Wyoming big sagebrush plants within 18 months of chemical treatment, but through recruitment plant numbers equaled or exceeded pretreatment density $\left(\right.$ plants $/ \mathrm{m}^{2}$ ) at 3 of the 8 sites and were increasing at other locations near the study's end. Wyoming big sagebrush canopy cover averaged $<2 \%$ the first 10 years after herbicide treatment but had returned to near pretreatment levels ( $>15 \%)$ at 2 sites, to between $5 \%$ and $10 \%$ at 4 sites, and to less than $3 \%$ at the remaining 2 sites. Treatment life was projected to exceed 35 years for 6 of the 8 study sites. Higher rates of tebuthiuron generally extended treatment life. Annual average perennial grass yield increased on treated areas relative to untreated rangeland at all study sites over the 20-year study period. Grass yield was highly variable between years, with pronounced increases when weather and environmental conditions were favorable for grass growth. A nonlinear S-shaped curve best described overstory-understory relationships and also defined the time path of Wyoming big sagebrush recovery, which differed by study site.
\end{abstract}

\section{Resumen}

Datos obtenidos durante un periodo de 20 años en ocho sitios en el Noroeste de Nuevo México fueron usados para determinar la recuperación de "Wyoming big sagebrush" (Artemisia tridentata ssp. wyomingensis Beetle and Young) después de control con "tebuthiuron" ( $N$-[5-(1,1-dimethylethyl)-1,3,4-thiadiazol-2-yl]-N-N'-dimethylurea), y para relacionar la ganancia del estrato vegetal de pastos perennes con la cobertura del estrato arbustivo. El "tebuthiuron” eliminó entre el 80 y el $95 \%$ de las plantas maduras de "Wyoming big sagebrush" dentro de 18 meses después del tratamiento químico, pero debido a la recuperación el número de plantas igualó o excedió la densidad de pre-tratamiento (plantas $/ \mathrm{m}^{2}$ ) en 3 de los 8 sitios y se incrementó en los otros sitios cerca del término del estudio. La cobertura promedio de "Wyoming big sagebrush" fue $<2 \%$ los primeros 10 años después del tratamiento con el herbicida, pero regresó próximo a los niveles de pre-tratamiento ( $>15 \%$ ) en 2 sitios, entre $5 \%$ y $10 \%$ en 4 sitios, y a menos de $3 \%$ en los 2 sitios restantes. La vida proyectada del tratamiento excedió los 35 años en 6 de los 8 sitios de estudio. Altos niveles de "tebuthiuron" generalmente extendieron la vida del tratamiento. El promedio anual de ganancia en producción de pastos perennes en áreas tratadas comparadas con pastizales no tratados se incrementó en todos los sitios a lo largo del periodo de estudio de 20 años. La ganancia de pasto fue altamente variable entre años, con pronunciados incrementos cuando las condiciones climáticas y ambientales fueron favorables para el crecimiento del pasto. Una curva no linear de forma $S$ fue la que mejor describió las relaciones entre el estrato vegetal y el estrato arbustivo y también definió la ruta de tiempo de recuperación del "Wyoming big sagebrush," la cual fue diferente para cada sitio.

Key Words: Artemisia tridentata ssp. wyomingensis Beetle and Young, sagebrush control, succession, brush control, overstoryunderstory relationships, range improvement

\section{INTRODUCTION}

Big sagebrush (Artemisia tridentata Nutt.) recovery after plant control, whether by fire, herbicide, or mechanical methods, is influenced by a myriad of localized factors, but with time the

Research was supported by New Mexico State University's Agricultural Experiment Station.

Correspondence: Kirk C. McDaniel, Dept of Animal and Range Sciences, P0 Box 30003, MSC 3-I, New Mexico State University, Las Cruces, NM 88003. Email: kmcdanie@nmsu.edu

Manuscript received 5 January 2004; manuscript accepted 9 July 2004. shrub is expected to reoccupy areas from which it has been removed (Sneva 1972). Exceptions may result when external factors like drought, annual weed invasion, or wildfire retard or prevent shrub recruitment and recovery (Watts and Wambolt 1996; Wambolt et al. 2001). Recovery rates following control may also be related to understory condition and site potential at the time of treatment (Hedrick et al. 1966), big sagebrush seed availability and propagation success (Young and Evans 1989), follow-up grazing management (Frischknecht and Plummer 1955; Johnson 1969), natural fire occurrence (Wright and Bailey 1982), big sagebrush 
Table 1. Description of study locations.

\begin{tabular}{|c|c|c|c|c|c|c|c|}
\hline Research location & $\begin{array}{c}\text { Type of } \\
\text { application }\end{array}$ & $\begin{array}{l}\text { Year of } \\
\text { treatment }\end{array}$ & $\begin{array}{l}\text { Average } \\
\text { rainfall } \\
(\mathrm{cm})\end{array}$ & $\begin{array}{l}\text { Elevation } \\
(\mathrm{m})\end{array}$ & Vegetation type & $\begin{array}{l}\text { Soil series and } \\
\text { family name }\end{array}$ & Soil texture \\
\hline Bloomfield & Hand applied & 1981 & 25.0 & 1920 & $\begin{array}{l}\text { Blue grama-Galleta-Sand } \\
\text { dropseed }\end{array}$ & Shiprock Typic Haplargid & Sandy loam \\
\hline Cedar Hills & Hand applied & 1981 & 22.5 & 1798 & Galleta-Squirreltail & Doak Typic Haplargid & Loam \\
\hline Gobernador & Hand applied & 1981 & 38.0 & 2012 & Galleta-Blue grama-mixed & $\begin{array}{l}\text { Del Rio Loam Ustollic } \\
\text { Haplargid }\end{array}$ & Loam \\
\hline Taos & Hand applied & 1981 & 31.8 & 2073 & Blue grama-annual grasses & Vibo aridic Haplustalfs & Sandy loam \\
\hline Navajo City & Aerial & 1982 & 38.0 & 2134 & Galleta-Blue grama-mixed & $\begin{array}{l}\text { Del Rio Loam Ustollic } \\
\text { Haplargid }\end{array}$ & Loam \\
\hline Tres Piedras North & Aerial & 1982 & 40.5 & 2438 & Western wheatgrass-Blue grama & Servilleta Ustollic Haplargid & Silty clay loam \\
\hline Tres Piedras Middle & Aerial & 1982 & 38.0 & 2286 & $\begin{array}{c}\text { Crested wheatgrass-Western } \\
\text { wheatgrass-Blue grama }\end{array}$ & Hernandez Ustollic Haplargid & Fine sandy loam \\
\hline Tres Piedras South & Hand applied & 1983 & 38.0 & 2286 & $\begin{array}{c}\text { Crested wheatgrass-Western } \\
\text { wheatgrass-Blue grama }\end{array}$ & Hernandez Ustollic Haplargid & Fine sandy loam \\
\hline
\end{tabular}

subspecies (Bartolome and Heady 1978; Maier et al. 2001), initial treatment success (Weldon et al. 1958; Bartolome and Heady 1978), and various localized weather, environmental, and microclimatic effects (Bleak and Miller 1955; Johnson and Payne 1968; Johnson 1969; Maier et al. 2001).

Longevity estimates regarding big sagebrush control practices are variable, but in general, herbicide control treatments are reported to be long lived. Sturges (1993) reported mountain big sagebrush (A. tridentata ssp. vaseyana Ryb. Beetle) canopy cover on nearby untreated rangeland averaged $15 \%$, but only about $1.5 \% 20$ years after spraying 2,4-D (2,4-dichlorophenoxy acetic acid) near Saratoga, Wyoming. Baxter (1998) examined big sagebrush recovery after treatment with low tebuthiuron rates $(<0.36 \mathrm{~kg}$ active ingredient [ai]/ha) and reported canopy cover declined from $>20 \%$ prior to treatment to $11 \%$ at Albion, Idaho (17 years posttreatment); $5 \%$ at Woodruff, Utah (10 years); and to about $11 \%$ at Mountain Home, Idaho (14 years). Other studies report treatment longevity of 12-30 years for both burning and chemical control of either mountain or Wyoming big sagebrush (Sneva 1972; Harniss and Murray 1973; Watts and Wambolt 1996; Wambolt et al. 2001). Relatively short-lived treatments have also been reported whereby sagebrush canopy cover increased soon after treatment and associated forage growth declined to pretreatment production levels within 6-10 years (Johnson 1969; Thilenius and Brown 1974).

To predict plant community change, it is important to know how quickly a shrub targeted for control is likely to reoccupy an area and how increasing overstory cover influences understory plant growth (Scrifres 1980). Besides ecological considerations, this information is important for making stocking rate decisions and for determining the economic feasibility and optimal frequency of brush control treatments. The objective of this research was to model Wyoming big sagebrush recovery after tebuthiuron treatments in the Colorado Plateau region of northwestern New Mexico. Measurements of Wyoming big sagebrush recovery included the change in canopy cover $(\%)$ and shrub density (plants $/ \mathrm{m}^{2}$ ) over a 20year period. Equations expressing overstory-understory rela- tionships for Wyoming big sagebrush are also estimated. In a companion paper, Torell et al. (2005) use these estimates of recovery rates and overstory-understory relationships to investigate the economics and optimal frequency of Wyoming big sagebrush control when added forage for livestock and wildlife is the measured benefit of the treatment. Optimal timing of sagebrush control when other nonlivestock resource values are considered is also discussed in the companion paper.

\section{METHODS}

\section{Study Sites and Tebuthiuron Treatments}

Eleven study sites were originally established in 1981-1983 to determine the optimal formulation and tebuthiuron application rate for Wyoming big sagebrush control in northwestern New Mexico (McDaniel and Balliete 1986), but 3 sites that were later disturbed are not included in this study. Four sites (near Bloomfield, Cedar Hills, Gobernador, and Taos, New Mexico; Table 1) were established in May 1981 to examine hand application of tebuthiuron using $10 \%$ and $20 \%$ formulated pellets. Tebuthiuron rates were $0.5,0.8$, and $1.1 \mathrm{~kg}$ ai/ha. Regardless of location, there was no difference in Wyoming big sagebrush control by common formulated rates (McDaniel and Balliette 1986). Thus, for this study, formulated treatments were combined, and only ai rates were compared. Experimental plots were 46 by $46 \mathrm{~m}$ and arranged in a randomized complete block design with 4 replications. Untreated plots were randomly located among treated areas.

In autumn 1982, tebuthiuron was aerially applied near Navajo City, New Mexico, and at 2 locations near Tres Piedras, New Mexico (North and Middle sites; Table 1). In spring 1983, tebuthiuron was applied by hand scattering pellets at another site near Tres Piedras (South site). Based partially on results from the 1981 experiment, only $20 \%$ formulated pellets were applied at these locations, and tebuthiuron rates ranged from 0.3 to $0.9 \mathrm{~kg}$ ai/ha. Aerial tebuthiuron applications were made as single treatments to large plots measuring 100 by $800 \mathrm{~m}$. Plots were placed side by side with 60-m untreated areas between treated plots at each location. At the Tres Piedras South site, where tebuthiuron was applied by hand scattering, 
rates were $0.4,0.5,0.6,0.7$, and $0.9 \mathrm{~kg}$ ai $/$ ha plus untreated plots. Experimental plots were 46 by $46 \mathrm{~m}$ and arranged in a randomized complete block design with 2 replications.

As described in more detail by McDaniel and Balliette (1986) and McDaniel et al. (1992), study sites were different in average annual precipitation, soil texture, and, most important, understory vegetation composition (Table 1). Wyoming big sagebrush was the primary subspecies found on all study sites, but mountain and basin big sagebrush (A. tridentata ssp. tridentata) were occasionally found at the Tres Piedras sites. When the study began, all sites had dense stands of Wyoming big sagebrush ranging in height from 0.1 to $1.5 \mathrm{~m}$, not including seedlings (McDaniel et al. 1992). Before herbicide treatment, average canopy cover on untreated areas ranged from $13 \%$ at the Bloomfield site to $24 \%$ at the Taos site.

\section{Wyoming Big Sagebrush Sampling}

Field sampling was conducted in late summer near the end of the annual growing season. In general, Wyoming big sagebrush did not succumb to tebuthiuron until the second growing season following treatment (ie, 18-24 months posttreatment). Thus, detailed shrub measurements were initiated in 1982 following spring 1981 treatments and in 1984 following fall 1982 and spring 1983 treatments. All study sites were sampled in 1987, 1993, 1998, and 2001. At hand-applied tebuthiuron study sites, $230-\mathrm{m}$ transects were placed in each treated and untreated experimental plot to determine canopy cover using the line intercept method (Canfield 1941; Bonham 1989). At aerialapplied tebuthiuron sites, 4 50-m transects were randomly placed parallel and equal distance apart in a perpendicular direction to the flight path in each experimental plot. All live shrub canopy segments $>3 \mathrm{~cm}$ that overlapped a line were measured for calculation of percent canopy cover. Wyoming big sagebrush density was determined using 1-m-wide belt transects, centered on the line intercept transects. Counts of only live shrubs were made, with partially defoliated plants considered alive. Established seedlings $(3-10 \mathrm{~cm}$ height $)$ and mature $(>10$ $\mathrm{cm}$ height) plants were counted separately. Newly emerged seedlings $(<3 \mathrm{~cm}$ height) were noted as present, but densities were not determined because they often occurred in dense clusters and sporadic groups. Survival of newly emerged seedlings is typically low (Young and Evans 1989); thus, most plants we considered to be established seedlings were probably 6 months of age or older.

According to analysis of variance (ANOVA), there was no difference in shrub measurements (canopy cover or density) by site and tebuthiuron rates for data obtained before 1993. Thus, data collected in earlier years were combined. Separate analyses were conducted by site for combined data and for data obtained in 1993, 1998, and 2001. Dependent variables included Wyoming big sagebrush density measured as the number of seedling and mature plants, and percent canopy cover. A randomized block design with data from subsampling along lines in each plot was used to calculate the error term in the ANOVA model.

\section{Herbaceous Vegetation Sampling}

Estimates of herbaceous standing crop (yield) were obtained using double sampling procedures (Bonham 1989). Plant weights were estimated separately by grass and broadleaf species. Data results through 1990 were presented in McDaniel et al. (1992). For this study, only perennial grass yield data are included in the overstory-understory analyses. At study sites where tebuthiuron was hand applied (Table 1), grass yield was double sampled in 10 $0.25-\mathrm{m}^{2}$ quadrants that were placed along 2 sample lines located diagonally across each plot. At the 3 aerial-applied study sites, grass yield was determined from $100.25-\mathrm{m}^{2}$ quadrants placed along 4 sample lines located at the belt transects where sagebrush density and cover were estimated. Coinciding with shrub measurements, grass yield was determined in all experimental plots and locations in 1993, 1998, and 2001. Grass yield was also recorded in experimental plots treated with tebuthiuron at the $0.5 \mathrm{~kg} / \mathrm{ha}$ rate and untreated control plots in 1981, 1982, 1983, 1986, 1987, 1988, 1989, 1990, 1992, 1994, and 1996. Sampling at the hand-applied Tres Piedras South site and the aerial-applied sites was initiated in 1986. Data were not gathered in 1988 at the Navajo City site because of adverse weather conditions during the measurement period.

\section{Estimating Wyoming Big Sagebrush Canopy Cover Recovery}

Nonlinear regression models were used to evaluate canopy cover change over time. A sigmoid-shaped exponential curve best described the recovery process, following ecological relationships summarized by Scrifres et al. (1982) and Masters and Sheley (2001). The equation as specified assumes that after shrub control there is a lag phase where the plant population remains small and localized. With time, the shrub population increases and expands exponentially until a maximum sustainable population is realized. A 5-parameter sigmoidal growth curve originally defined by Jameson (1967) was adapted for estimation using nonlinear (PROC NLIN) regression routines in SAS $^{1}$ (Freund and Littell 2000):

$$
\ln (Y)=H+A\left(1-e^{-B * T I M E}\right)^{M}
$$

Separate equations were estimated by site and by tebuthiuron treatment rate. The dependent variable $Y$ was defined to be percent sagebrush canopy cover. The equation was estimated as the natural $\log$ of $Y$ because estimating the model in log form solved problems with heteroscedasticity (increasing variance over time) observed in initial regression models. The parameters $H, A, B$, and $M$ are estimated. TIME is the number of years since treatment. In this application, $H$ defines the lower asymptote of the curve, and $H+A$ defines the upper asymptote; $B$ provides the curvature for the regression line, and $M$ adjusts the inflection point.

Within the time frame of the 20-year study, Wyoming big sagebrush canopy cover on treated areas had not returned to that of untreated areas except at Taos. Thus, to estimate equation 1 it was necessary to impose restrictions on $H$ and $A$. The nonlinear iterative search procedure used by SAS would not converge without imposing these restrictions. Wyoming big sagebrush defoliation was $>99 \%$ in most instances within 24 months of herbicide treatment (McDaniel and Balliette 1986).

\footnotetext{
${ }^{1}$ The sigmoid shape can also be approximated using a logistic function as defined by Watts and Wambolt (1996) in a similar evaluation of sagebrush recovery.
} 
Thus, the assumption was made that canopy cover would be reduced to $0.3 \%$ (a minimal level) following herbicide control. Estimated in $\log$ form, the imposed restriction was $H=$ $\ln (0.3)=-1.20$.

The second restriction imposed was that canopy cover will eventually return to a long-term equilibrium. The equilibrium level was considered to be the average sagebrush canopy cover of untreated areas at each site. The specific assumption was that $H+A$ must equal the natural log of average canopy cover on untreated control plots. The parameter $A$ was the same across treatment rates, but it was different by site because average canopy cover on control areas was different by site. The estimated parameters $B$ and $M$ were allowed to vary by site and across treatment rates.

The restrictions on $H$ and $H+A$ define where each equation begins and ends. The time frame in which equilibrium canopy cover is expected to be reached depends on the rate of sagebrush recovery observed over the 20-year study period.

A partial $F$ test (Greene 2003) was used to test whether sagebrush recovery paths at a particular study site varied for different herbicide treatment rates. The unrestricted models were compared to alternative restricted models, where data were pooled across treatments with $B$ and $M$ restricted to be the same across treatment rates. If $B$ and $M$ were not found to be statistically different by herbicide treatment, new equations were estimated that combined data for these treatment rates.

\section{Estimating Herbaceous Vegetation Response}

Jameson (1967) originally proposed the sigmoidal growth curve described previously as a general model for overstoryunderstory relationships. The functional form is flexible and unique in this application because, depending on parameter estimates, the shape of the curve can range from sigmoid to exponential, which are the common shapes defined for overstory-understory relationships (Ffolliot and Clary 1972). The curve will be exponentially decreasing when $M$ is less than 1 , and the length of the flat upper asymptote will increase when $M$ increases above 1 (Jameson 1967).

The nonlinear sigmoid curve estimated was

$$
Y=H+H_{p} D+\left(A+A_{p} D\right) *\left(1-e^{-B * X}\right)^{M}
$$

The dependent variable $Y$ was defined as perennial grass yield $(\mathrm{kg} / \mathrm{ha})$. The independent variable $X$ was percent sagebrush cover.

Initial observation and analysis indicated there was significant variation in grass yield between years and by study site during the 20-year study period. This was expected because variation in annual precipitation is a dominant factor causing herbage yield fluctuations on semiarid rangelands. We explored options to include rainfall as an explanatory variable and as a shifter in overstory-understory equations, similar to the approach used by McDaniel et al. (1993). However, using this approach proved unsatisfactory for this study. Numerous environmental and site-specific variables could potentially be included as shifters, for example, soil temperature and/or timing of precipitation (Bork et al. 2001). Incorporating these environmental variables would be a preferred shifter in the model if data were available. As an alternative, dummy variables were defined to shift the curve during productive years (i.e., $D=1$ during years when grass yield was above average, and $D=0$ during below-average years). The parameter $H_{p}$ shifts the intercept during above-average years. Similarly, $A_{p}$ is a shifter for $A$ during above-average years; $H+A$ defines the lower asymptote for below-average years, and $H+H_{p}+A+A_{p}$ defines the lower asymptote during above-average years.

\section{RESULTS}

\section{Wyoming Big Sagebrush Mortality, Density, and Cover}

Wyoming big sagebrush mortality from tebuthiuron treatments at the 8 sites included in this study was partially summarized in McDaniel et al. (1992). As noted, within 24 months of tebuthiuron application, mortality averaged about $80 \%$ at the $0.4-\mathrm{kg} / \mathrm{ha}$ rate, which was significantly less than higher rates $(\geq 0.5 \mathrm{~kg} / \mathrm{ha})$, where Wyoming big sagebrush mortality was not different and exceeded $90 \%$. Canopy cover was reduced by about $90 \%$ on experimental plots treated at the $0.4-\mathrm{kg} / \mathrm{ha}$ rate and usually $>99 \%$ at rates $\geq 0.5 \mathrm{~kg} / \mathrm{ha}$. The $0.3-\mathrm{kg} / \mathrm{ha}$ tebuthiuron rate was applied only at the Middle Tres Piedras site, resulting in $65 \%$ mortality, and canopy cover was reduced by $80 \%$.

During the first 8-10 years after tebuthiuron application, newly emerged Wyoming big sagebrush seedlings $(<3 \mathrm{~cm}$ height) were periodically noted at a particular study site, but most failed to establish (data not shown; McDaniel et al. 1992). A complete count of established seedlings $(3-10 \mathrm{~cm}$ height) taken within experimental plots in 1993, 1998, and 2001 indicated that densities varied widely by location, year, and treatment rate (Table 2). Wyoming big sagebrush is a prolific seed producer but lacks specialized structures for long-range dispersal, and seed generally remains viable for only a brief period, often less than a year (Young and Evans 1989). We speculate that mature sagebrush plants that survived tebuthiuron treatment were the source for seedlings produced in experimental plots. Wyoming big sagebrush propagation is influenced by the timing, quantity, and frequency of rainfall, and seedling establishment was expected to vary by location and treatments within a site (Young and Evans 1989; Masters and Sheley 2001). Consistent with observations of expected variability, in 1993, Wyoming big sagebrush seedling density was significantly higher in untreated areas than in tebuthiuron-treated plots at the 3 Tres Piedras study locations and the Gobernador and Bloomfield sites (Table 2). Conversely, seedling densities were higher in plots treated with tebuthiuron at the $0.5-\mathrm{kg} / \mathrm{ha}$ rate compared to untreated areas at the Cedar Hills, Taos, and Navajo City study sites. In 1998, the trend of either higher or lower Wyoming big sagebrush seedling numbers in untreated or $0.5-\mathrm{kg} / \mathrm{ha}$ tebuthiuron-treated areas was similar by location to that observed in 1993. By 2001, fewer seedlings were counted at all study sites relative to 1993 and 1998 samplings. This occurred in part because seedlings developed into the mature class and because Wyoming big sagebrush propagation was low from drought conditions in New Mexico from 1998 to 2001.

During the 20-year study, mature Wyoming big sagebrush $(>10 \mathrm{~cm}$ height $)$ density in untreated areas remained relatively unchanged by site (Table 2 ). In contrast, mature plant density 


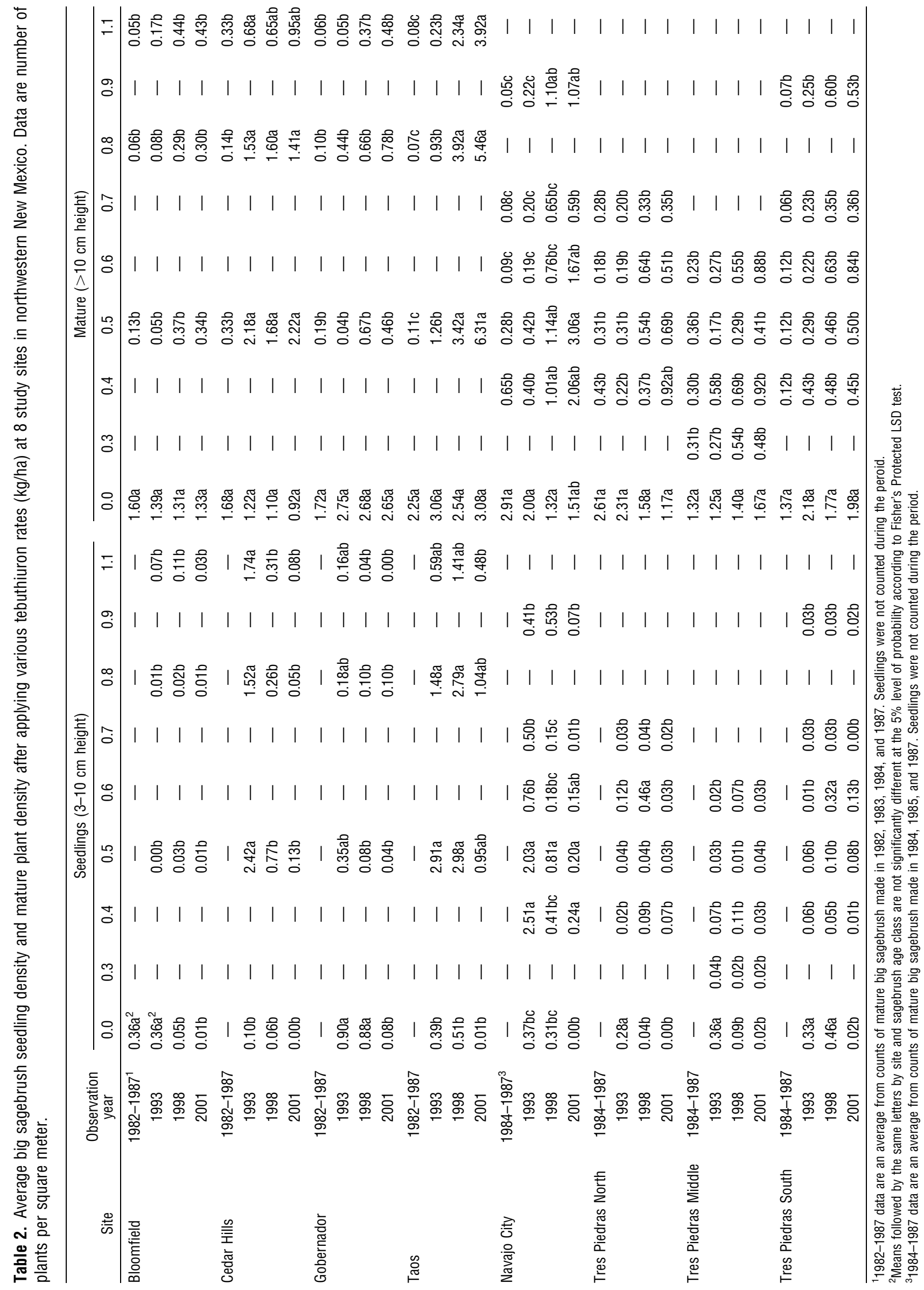



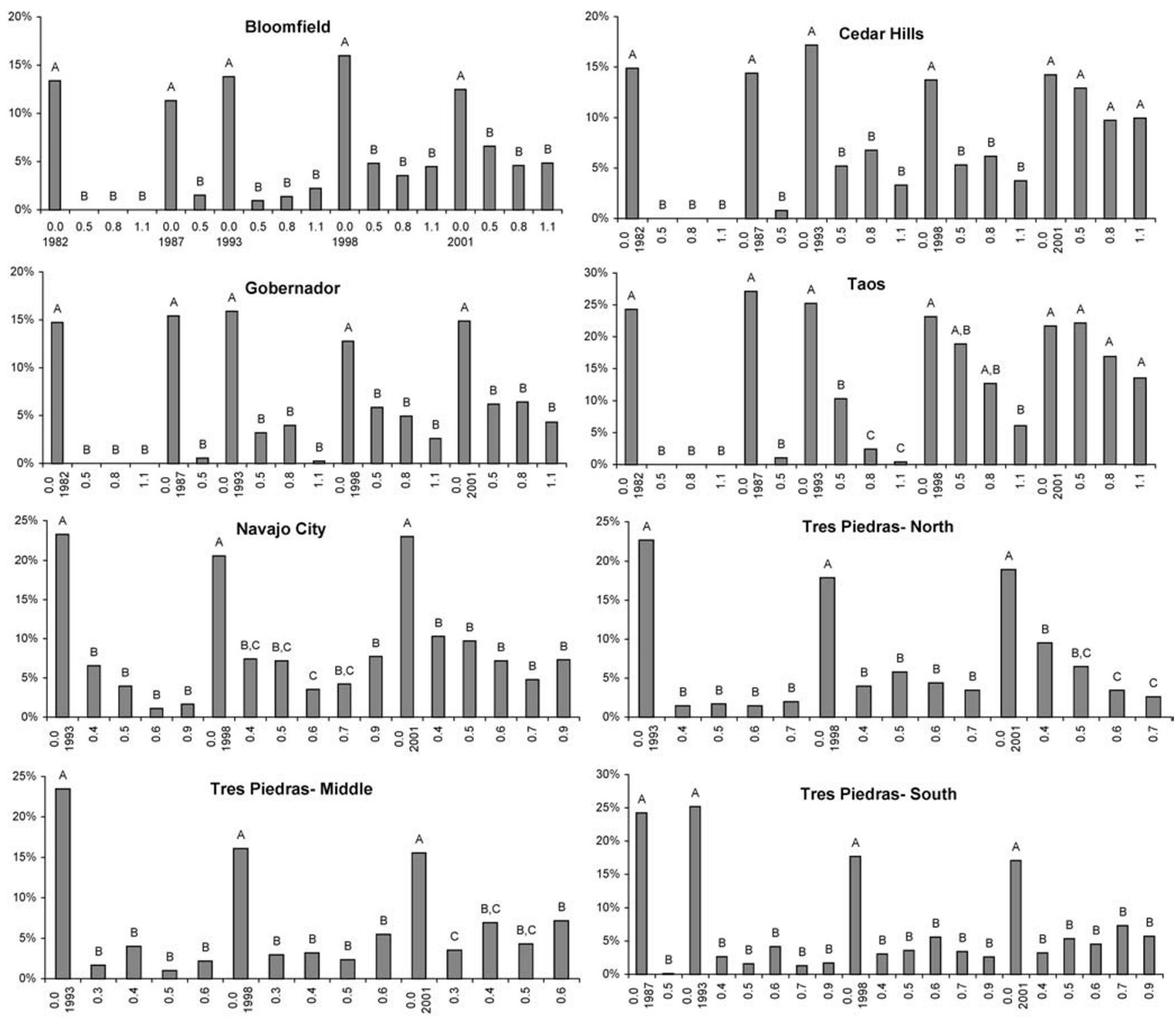

Note: Within the same year and study site treatments followed by the same letter are not statistically different. Statistical comparisons are not made across years

Figure 1. Average Wyoming big sagebrush canopy cover in the years following control with different rates of tebuthiuron by site and herbicide treatment rate ( $\mathrm{kg}$ active ingredient [ai]/ha).

declined $(P<0.05)$ in all experimental plots treated with tebuthiuron, regardless of location, compared to untreated rangeland when sampled through 1987 . Only at the Taos and Navajo City locations were there more, mature plants at the $0.5 / \mathrm{kg} / \mathrm{ha}$ rate than in plots treated with higher tebuthiuron rates. By 1993, mature plant density was nearly equivalent in all treated and untreated plots at the Cedar Hills location, and by 1998, the same was true at the Taos and Navajo City locations. The remaining 5 sites had fewer $(P<0.05)$ mature plants in tebuthiuron treatments in 1998 and 2001 than untreated areas, except in plots treated at the $0.4-$ and $0.5-\mathrm{kg} / \mathrm{ha}$ rates at Tres Piedras Middle.

Wyoming big sagebrush canopy cover was significantly reduced for all tebuthiuron treatments compared to untreated areas through 1998. Taos was the only exception, where cover was not statistically different at the $0.5-$ and $0.8-\mathrm{kg} / \mathrm{ha}$ rates compared to untreated plots (Fig. 1). By 2001, canopy cover was not different $(P<0.05)$ among treated and untreated plots at the Cedar Hills site. At the Taos and Cedar Hills sites, canopy cover was near $10 \%$ or higher, whereas cover at the Bloomfield and Gobernador sites averaged about 5\% across tebuthiuron treatments.

At the 4 study sites established in 1982 and 1983, canopy cover was similar among tebuthiuron treatments but less than in untreated areas at the Tres Piedras South and Navajo City locations. At the Tres Piedras North site, canopy cover was significantly higher in plots treated at the $0.4-\mathrm{kg} / \mathrm{ha}$ rate than $0.6-$ and $0.7-\mathrm{kg} / \mathrm{ha}$ rates, but these were similar to cover in the $0.5-\mathrm{kg} / \mathrm{ha}$ treatment. At the Tres Piedras Middle site, canopy cover was unexpectedly less at the $0.3 \mathrm{-kg} / \mathrm{ha}$ compared to the $0.6-\mathrm{kg} / \mathrm{ha}$ treatment, but these rates were not different from $0.4-$ and $0.5-\mathrm{kg} / \mathrm{ha}$ treatments. 
Table 3. Regression parameter estimates for sagebrush recovery equations by site and treatment rate. ${ }^{1}$

\begin{tabular}{|c|c|c|c|c|c|c|c|}
\hline Site & $\begin{array}{l}\text { Treatment } \\
\text { rate }\end{array}$ & $n$ & A & B & $\mathrm{M}$ & $R^{2}$ & MSE \\
\hline \multirow[t]{8}{*}{ Bloomfield } & 0.5 & 44 & 3.795 & 0.032 & 0.778 & 0.21 & 1.176 \\
\hline & & & & $(0.023)$ & $(0.415)$ & & \\
\hline & 0.8 & 24 & 3.795 & 0.088 & 2.473 & 0.46 & 0.928 \\
\hline & & & & $(0.061)$ & (2.971) & & \\
\hline & 1.1 & 24 & 3.795 & 0.087 & 2.166 & 0.47 & 0.951 \\
\hline & & & & $(0.060)$ & (2.519) & & \\
\hline & Pooled & 92 & 3.795 & 0.052 & 1.160 & 0.35 & 1.031 \\
\hline & & & & $(0.018)$ & $(0.434)$ & & \\
\hline \multirow[t]{8}{*}{ Cedar Hills } & 0.5 & 44 & 3.910 & 0.170 & 3.390 & 0.85 & 0.259 \\
\hline & & & & $(0.022)$ & $(0.871)$ & & \\
\hline & 0.8 & 24 & 3.910 & 0.108 & 1.831 & 0.61 & 0.820 \\
\hline & & & & $(0.050)$ & (1.599) & & \\
\hline & 1.1 & 24 & 3.910 & 0.100 & 2.451 & 0.46 & 1.195 \\
\hline & & & & $(0.070)$ & $(3.20)$ & & \\
\hline & Pooled* & 92 & 3.910 & 0.114 & 2.030 & 0.63 & 0.694 \\
\hline & & & & $(0.020)$ & $(0.61)$ & & \\
\hline \multirow[t]{8}{*}{ Gobernador } & 0.5 & 44 & 3.891 & 0.135 & 3.239 & 0.71 & 0.489 \\
\hline & & & & $(0.025)$ & $(1.13)$ & & \\
\hline & 0.8 & 24 & 3.891 & 0.086 & 1.442 & 0.73 & 0.398 \\
\hline & & & & $(0.029)$ & $(0.77)$ & & \\
\hline & 1.1 & 24 & 3.891 & 0.161 & 13.193 & 0.51 & 0.834 \\
\hline & & & & $(0.065)$ & (15.94) & & \\
\hline & Pooled* & 92 & 3.891 & 0.094 & 2.169 & 0.57 & 0.708 \\
\hline & & & & $(0.019)$ & $(0.72)$ & & \\
\hline \multirow[t]{8}{*}{ Taos } & 0.5 & 44 & 4.391 & 0.259 & 6.180 & 0.94 & 0.144 \\
\hline & & & & $(0.023)$ & $(1.31)$ & & \\
\hline & 0.8 & 24 & 4.391 & 0.347 & 94.818 & 0.82 & 0.568 \\
\hline & & & & $(0.072)$ & (101.10) & & \\
\hline & 1.1 & 24 & 4.391 & 0.304 & 95.574 & 0.84 & 0.436 \\
\hline & & & & $(0.056)$ & $(91.70)$ & & \\
\hline & Pooled* & 92 & 4.391 & 0.148 & 3.016 & 0.69 & 0.812 \\
\hline & & & & $(0.023)$ & $(0.97)$ & & \\
\hline \multirow[t]{14}{*}{ Navajo City } & 0.4 & 12 & 4.303 & 0.051 & 0.553 & $0.08^{\star *}$ & 0.713 \\
\hline & & & & (8) & $(0.880)$ & & \\
\hline & 0.5 & 20 & 4.303 & 0.080 & 0.956 & 0.75 & 0.049 \\
\hline & & & & $(0.017)$ & $(0.26)$ & & \\
\hline & 0.6 & 12 & 4.303 & 0.217 & 18.658 & 0.66 & 0.654 \\
\hline & & & & $(0.065)$ & (18.66) & & \\
\hline & 0.9 & 12 & 4.303 & 0.208 & 11.052 & 0.59 & 0.555 \\
\hline & & & & (8) & $(9.79)$ & & \\
\hline & 0.4 and 0.5 & 32 & 4.303 & 0.070 & 0.807 & 0.27 & 0.317 \\
\hline & & & & $(0.033)$ & $(0.45)$ & & \\
\hline & 0.6 and 0.9 & 24 & 4.303 & 0.208 & 13.370 & 0.60 & 0.663 \\
\hline & & & & $(0.046)$ & $(9.02)$ & & \\
\hline & Pooled* & 56 & 4.303 & 0.113 & 2.143 & 0.29 & 0.722 \\
\hline & & & & $(0.032)$ & $(1.07)$ & & \\
\hline \multirow{6}{*}{$\begin{array}{l}\text { Tres Piedras } \\
\text { North }\end{array}$} & 0.4 & 12 & 4.188 & 0.184 & 8.477 & 0.64 & 0.471 \\
\hline & & & & $(0.055)$ & $(6.91)$ & & \\
\hline & 0.5 & 28 & 4.188 & 0.118 & 2.657 & 0.93 & 0.088 \\
\hline & & & & $(0.012)$ & $(0.41)$ & & \\
\hline & 0.6 & 12 & 4.188 & 0.072 & 1.684 & $0.25^{\star *}$ & 0.671 \\
\hline & & & & $(0.057)$ & $(1.80)$ & & \\
\hline
\end{tabular}

Table 3. Continued.

\begin{tabular}{|c|c|c|c|c|c|c|c|}
\hline Site & $\begin{array}{l}\text { Treatment } \\
\text { rate }\end{array}$ & $n$ & A & B & M & $R^{2}$ & MSE \\
\hline & 0.7 & 12 & 4.188 & 0.032 & 0.815 & $0.10^{* *}$ & 0.837 \\
\hline & & & & $(0.057)$ & (1.19) & & \\
\hline & 0.6 and 0.7 & 24 & 4.188 & 0.051 & 1.184 & 0.16 & 0.701 \\
\hline & & & & $(0.040)$ & $(0.99)$ & & \\
\hline & Pooled* & 48 & 4.188 & 0.095 & 2.151 & 0.59 & 0.454 \\
\hline & & & & $(0.017)$ & $(0.58)$ & & \\
\hline \multirow{14}{*}{$\begin{array}{l}\text { Tres Piedras } \\
\text { Middle }\end{array}$} & 0.3 & 12 & 4.081 & 0.072 & 1.772 & $0.28^{\star *}$ & 0.577 \\
\hline & & & & $(0.054)$ & $(1.79)$ & & \\
\hline & 0.4 & 12 & 4.081 & 0.025 & 0.379 & $0.13^{\star \star}$ & 0.245 \\
\hline & & & & $(0.038)$ & $(0.40)$ & & \\
\hline & 0.5 & 44 & 4.081 & 0.071 & 1.788 & 0.67 & 0.205 \\
\hline & & & & $(0.014)$ & $(0.39)$ & & \\
\hline & 0.6 & 12 & 4.081 & 0.117 & 2.410 & 0.45 & 0.333 \\
\hline & & & & $(0.049)$ & $(1.88)$ & & \\
\hline & 0.3 and 0.5 & 56 & 4.081 & 0.073 & 1.815 & 0.63 & 0.267 \\
\hline & & & & $(0.014)$ & $(0.40)$ & & \\
\hline & 0.4 and 0.6 & 24 & 4.081 & 0.070 & 1.039 & 0.28 & 0.319 \\
\hline & & & & $(0.034)$ & $(0.65)$ & & \\
\hline & Pooled* & 80 & 4.081 & 0.091 & 2.095 & 0.62 & 0.364 \\
\hline & & & & $(0.014)$ & $(0.46)$ & & \\
\hline \multirow{9}{*}{$\begin{array}{l}\text { Tres Piedras } \\
\text { South }\end{array}$} & 0.4 & 12 & 4.216 & 0.028 & 0.658 & $0.09^{* *}$ & 0.837 \\
\hline & & & & $(0.056)$ & $(0.98)$ & & \\
\hline & 0.5 & 16 & 4.216 & 0.168 & 6.608 & 0.74 & 0.588 \\
\hline & & & & $(0.044)$ & $(3.85)$ & & \\
\hline & 0.7 & 12 & 4.216 & 0.112 & 2.996 & 0.45 & 0.522 \\
\hline & & & & $(0.052)$ & (2.53) & & \\
\hline & 0.9 & 12 & 4.216 & 0.127 & 4.397 & 0.47 & 0.635 \\
\hline & & & & $(0.057)$ & $(4.02)$ & & \\
\hline & Pooled & 52 & 4.216 & 0.130 & 4.244 & 0.66 & 0.620 \\
\hline
\end{tabular}

\section{Wyoming Big Sagebrush Recovery Equations}

Regression parameters were estimated separately by study site and tebuthiuron treatment rate using the nonlinear regression model defined in equation 1 (Table 3). Those pooled regressions shown in the table with an asterisk $\left(^{*}\right)$ were significantly different across treatment rates using a partial $F$ test. Equations with $R^{2}$ values denoted by ** were not statistically significant at the $\alpha=0.05$ level. The asymptotic standard error of the estimate is shown in brackets.

Parameter $H$ was restricted to be -1.20 in all cases. Parameter $A$ was modified by site as determined by the restriction that $H+A$ must equal the natural $\log$ of average sagebrush canopy cover observed on untreated areas. ${ }^{2}$ Regardless of study site, statistical results were generally best at the $0.5-\mathrm{kg} / \mathrm{ha}$ rate compared to other tebuthiuron treatments.

\footnotetext{
${ }^{2}$ As an example of the calculation procedure, consider the Cedar Hills site. At this site, average canopy cover of untreated areas was $15 \%$, with the natural log being 2.71 . Parameter $H$ was restricted to -1.20 . Thus, the restriction that $H+A$ must equal 2.71 means $A$ was restricted to $3.91(H+A=-1.20+3.91=2.71)$.
} 
Sagebrush Canopy Cover (\%)
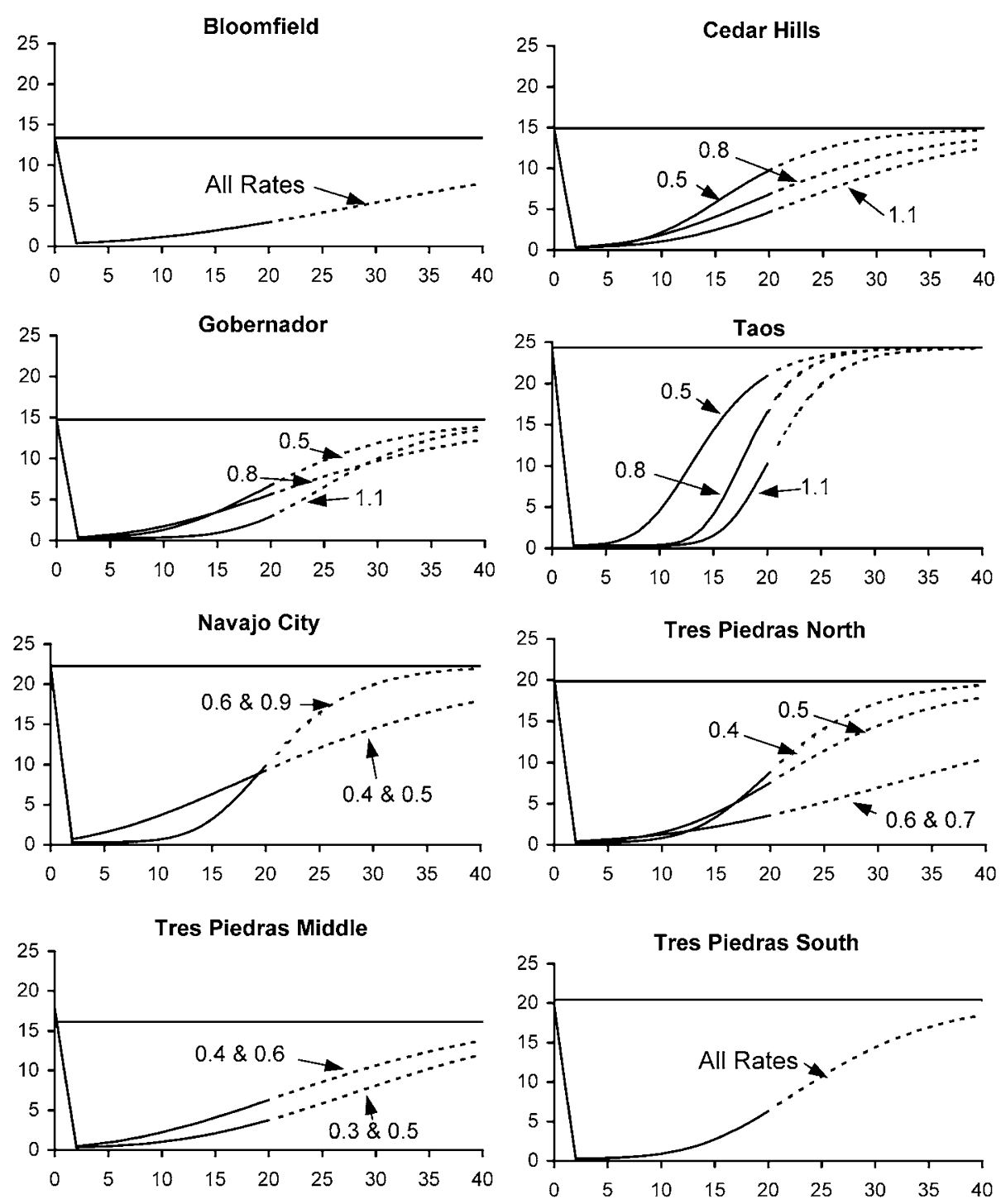

Number of years after treatment

Note: Regression parameter estimates are presented in Table 3. Multiple curves are shown for different rates only when statistically different. The average sagebrush canopy cover in untreated areas is shown as the line at the top of the curves.

Figure 2. Estimated Wyoming big sagebrush recovery in years following control with tebuthiuron (solid line) and projected values (dashed line) by site and herbicide treatment rate (kg active ingredient [ai]/ha).

This is partially because canopy cover was relatively high in the $0.5-\mathrm{kg} / \mathrm{ha}$ treatments compared to other rates by 2001 (Fig. 1) and because this was the only rate consistently included in all experiments, and thus the sample size was larger. The best statistical fit, as measured by the model $R^{2}$, was for the Taos study site at the $0.5-\mathrm{kg} / \mathrm{ha}$ rate, where canopy cover was near pretreatment levels at the study's end. In some instances, because of either high canopy cover variability or an inadequate sample size at a particular site, the regression model would not converge. This occurred at the $0.6-\mathrm{kg} / \mathrm{ha}$ rate at Tres Piedras South and at the $0.7-\mathrm{kg} / \mathrm{ha}$ rate at Navajo City. Regression equations are not shown in these cases.
Wyoming big sagebrush recovery by site was generally different by tebuthiuron rate, except at Bloomfield and Tres Piedras South, where canopy cover changes by herbicide rate were not statistically different using a partial $F$ test. It was anticipated that higher tebuthiuron rates would extend treatment life; this situation was true at Cedar Hills, Taos, and Tres Piedras North.

The recovery equations can be used to forecast how Wyoming big sagebrush canopy cover is likely to proceed in the future (Fig. 2), provided the future progression follows the assumed sigmoid shape suggested as a general ecological model of invasive processes by Masters and Sheley (2001). In general, canopy cover remained low or near the lower asymptote of the 
Tabe 4. Big sagebrush regression parameter estimates for overstory-understory relationships by site. ${ }^{1}$

\begin{tabular}{|c|c|c|c|c|c|c|c|c|}
\hline Site & $n$ & $\mathrm{H}$ & A & B & M & $\mathrm{Hp}$ & Ap & $R^{2}$ \\
\hline \multirow[t]{2}{*}{ Bloomfield } & 142 & 392.60 & -127.20 & 1.339 & 1233.60 & 679.60 & -656.70 & 0.74 \\
\hline & & $(24.80)$ & $(38.37)$ & (2.181) & (14 988.8) & (42.32) & $(60.76)$ & \\
\hline \multirow[t]{2}{*}{ Cedar Hills } & 141 & 412.00 & -191.40 & 0.788 & 223.30 & 415.90 & -459.50 & 0.57 \\
\hline & & $(49.50)$ & $(68.37)$ & $(1.291)$ & (2 029.3) & $(64.86)$ & $(93.77)$ & \\
\hline \multirow[t]{2}{*}{ Gobernador } & 141 & 419.20 & -205.60 & 0.424 & 21.76 & 791.40 & -738.60 & 0.76 \\
\hline & & $(27.15)$ & $(60.86)$ & $(0.471)$ & $(74.76)$ & $(48.91)$ & $(78.41)$ & \\
\hline \multirow[t]{2}{*}{ Taos } & 134 & 157.30 & -136.10 & 0.462 & 36.52 & 302.70 & -310.80 & 0.30 \\
\hline & & $(26.40)$ & (33.36) & $(0.554)$ & $(188.30)$ & $(48.91)$ & $(58.89)$ & \\
\hline \multirow[t]{2}{*}{ Navajo City } & 104 & 529.70 & -376.00 & 0.599 & 269.00 & 1010.60 & -941.30 & 0.81 \\
\hline & & $(40.06)$ & $(62.25)$ & $(0.490)$ & (1 207.2) & $(67.67)$ & $(100.10)$ & \\
\hline \multirow[t]{2}{*}{ Tres Piedras North } & 88 & 280.30 & -223.00 & 0.111 & 1.49 & 198.80 & -227.10 & 0.56 \\
\hline & & $(48.60)$ & $(153.10)$ & $(0.205)$ & (2.39) & $(46.85)$ & $(76.67)$ & \\
\hline \multirow[t]{2}{*}{ Tres Piedras Middle } & 124 & 278.00 & -134.50 & 0.795 & 1376.70 & 671.80 & -620.80 & 0.71 \\
\hline & & $(36.27)$ & (70.98) & (3.257) & (40 905.2) & (49.69) & $(87.83)$ & \\
\hline \multirow[t]{2}{*}{ Tres Piedras South } & 128 & 396.00 & -204.90 & 0.398 & 117.40 & 621.10 & -412.30 & 0.70 \\
\hline & & (41.63) & (99.99) & $(0.832)$ & (1 162.8) & $(63.44)$ & $(110.10)$ & \\
\hline
\end{tabular}

${ }^{1}$ Asymptotic standard errors are shown in parentheses.

S-shaped curve defined by equation 1 for the first 10 years after herbicide treatment. After this time, canopy cover began to increase exponentially at most sites. A similar S-shaped pattern of Wyoming big sagebrush recovery, but with a different time frame, was reported by Watts and Wambolt (1996) following burning, 2,4-D, plowing and seeding, and rotocutting treatments in southwestern Montana. Watts and Wambolt reported that Wyoming big sagebrush canopy cover following chemical and mechanical treatment returned to about $5 \%$ within 10 years of shrub control and to near untreated levels in about 20 years. Projections from our data (Fig. 2) indicate that Wyoming big sagebrush canopy cover in treated areas will approximate that of adjacent, untreated areas in 35-50 years. The Taos study site was an exception, as canopy cover returned to about $90 \%$ of that in untreated areas within the 20 -year study period. Taos was a relatively unproductive site, with little understory perennial vegetation prior to or after chemical treatment. This probably contributed to the rapid reinvasion of Wyoming big sagebrush on this site. Hedrick et al. (1966) and Schmisseur and Miller (1980) also reported that sites with little understory herbage responded poorly to sagebrush control treatments and respond with primarily increased production of annual grasses and with minimal treatment life.

\section{Overstory-Understory Relationships}

Regression equations defining overstory-understory relationships at the 8 study sites were statistically significant $(P>0.05$; Table 4 ). $R^{2}$ estimates ranged from a relatively low $30 \%$ at the Taos site, where the understory was dominated by annual grasses (Table 1), to $81 \%$ for the Navajo City site. The parameters $H_{p}$ and $A_{p}$ were statistically significant $(P>0.05)$ at all sites. Overstory-understory relationships, as indicated by the weighted average curves (Fig. 3), were sigmoid in shape with the estimated parameter $M$ far greater than 1 at all study locations except Tres Piedras North (Table 4).

In years favorable for grass growth, the upper asymptote of the sigmoid curve shifted dramatically upward, compared to below-average growth years, especially when Wyoming big sagebrush canopy cover was low ( $<$ about 6\%; Fig. 3). During below-average growth years, the asymptote remained relatively low and flat, indicating that even with sagebrush removed, grass yield will be retarded if environmental conditions are unfavorable. With some variation among study sites, the weighted average growth curves in Figure 3 indicate that grass yield can be expected to decline sharply once Wyoming big sagebrush canopy cover reaches a threshold level roughly between $6 \%$ and $9 \%$. Further, once canopy cover exceeds about $10 \%-12 \%$, grass yield suppression is maximized under the shrub.

The influence of Wyoming big sagebrush presence on average annual grass yield differed by study site (Fig. 3). The greatest grass response was at Navajo City, where the weighted average grass yield was about $1000 \mathrm{~kg} / \mathrm{ha}$ when sagebrush canopy cover was below $8 \%$. This compares to about $180 \mathrm{~kg} /$ ha when canopy cover exceeded $12 \%$. Taos and Tres Piedras North were the least productive sites before Wyoming big sagebrush control and predictably had the least grass response after treatment. Average grass response at the Bloomfield, Cedar Hills, and Gobernador sites was similar, moving from about $200 \mathrm{~kg} / \mathrm{ha}$ on untreated areas to about $600 \mathrm{~kg} / \mathrm{ha}$ on treated areas. Grass production at these locations tended to be bimodal with high yields in favorable growth years and low yields in unfavorable years (Fig. 3).

Combining overstory-understory relationships for the weighted average curve (Fig. 3), with estimates of how Wyoming big sagebrush canopy cover is expected to change with time (Fig. 2), provides a projection of expected average annual grass yield in years following brush control (Fig. 4). Consider as an example the $0.5-\mathrm{kg} / \mathrm{ha}$ treatment rate applied at the Cedar Hills site, where grass yield remained near peak levels for about 14 years (Fig. 2) until canopy cover reached about $6 \%$ (Fig. 3). It is projected to take nearly 40 years before Wyoming big sagebrush canopy cover will be equivalent in treated and untreated areas at Cedar Hills, but grass yield was similar in only about 20 years (Fig. 4). 

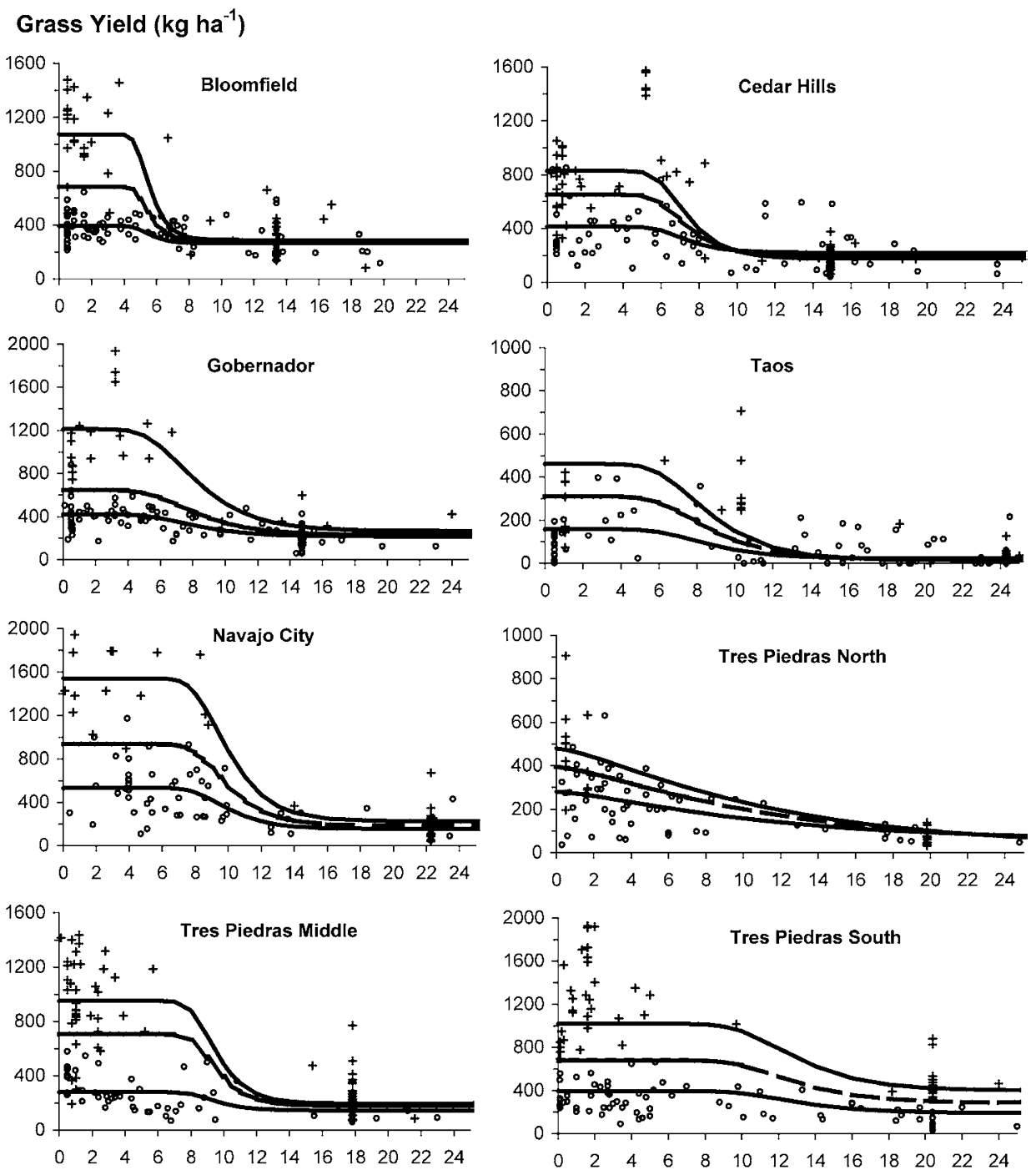

Sagebrush cover $(\%)$

Overstory-understory Curves

Top $\left(^{+}\right)$- Above average growth years

Bottom (o) - Below average growth years

Middle Line - Weighted average

Note: The Y-axis scale is different by site and 7 data points are beyond the scales shown.

Figure 3. Wyoming big sagebrush overstory-understory relationships by study site.

\section{MANAGEMENT IMPLICATIONS}

Wyoming big sagebrush overstory-understory relationships mirror the general shape found for many brush species with the curve S-shaped or convex to the origin and decreasing throughout (Bartlett and Betters 1983). This suggests that linear estimates of understory suppression are inadequate for Wyoming big sagebrush. It is important to appreciate that the overstory-understory curve is flexible and will change with environmental conditions. For example, the curve appears to be relatively flat in years that are poor for understory growth but rotates upward from the lower asymptote when growing conditions improve (Fig. 3). This is likely a continuous shift across changing weather and environmental conditions. The
Jameson (1967) equation is flexible and with modification can easily handle this shift in $H$ and $A$, provided an adequate variable capturing the influence of weather and environment can be measured and defined.

The shift in the overstory-understory curves among productive and nonproductive years highlights the importance of long-term vegetative sampling to account for the high variability in plant growth on rangelands. If vegetative sampling is limited to only highly productive or nonproductive years, then results used to explain overstory-understory relationships may be misleading. Further, the sigmoid curves suggest that complete shrub removal is not required to achieve a satisfactory increase in grass pro- 


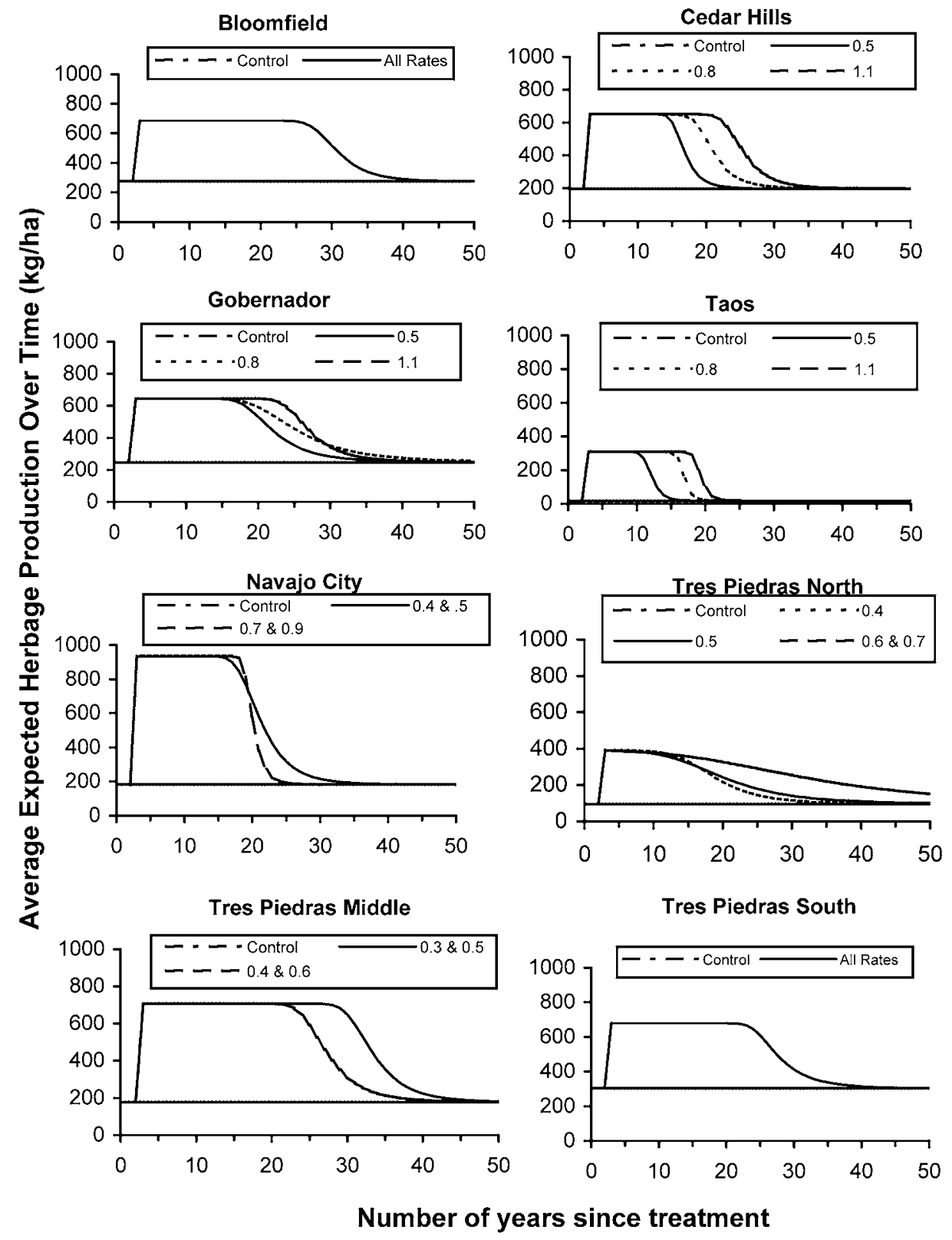

Note: Multiple curves are shown for different tebuthiuron rates only when treatment rate significantly affected the rate of sagebrush reinvasion. Graphs are drawn assuming peak herbaceous production will be reached 2 years after brush control.

Figure 4. Expected time path of annual average herbage production following Wyoming big sagebrush control with tebuthiuron.

duction. Wyoming big sagebrush reduced to a canopy cover below $6 \%-8 \%$ should give a significant grass response, but leaving a higher cover percentage will result in a shortened treatment life (Weldon et al. 1958; Johnson and Payne 1968; Johnson 1969).

With the exception of the Taos site that was never grazed throughout this study, our study areas were grazed at light to moderate levels. As noted by Sneva (1972), treatment life may be extended or shortened, depending on management and grazing use. However, we observed no evidence that follow-up man- agement was important in how quickly Wyoming big sagebrush recovered at the study sites. Rather, similar to the findings of Frischnecht and Plummer (1955) and Maier et al. (2001), the frequency of years favorable for brush seedling establishment following treatment was the most important single factor influencing Wyoming big sagebrush recovery. We agree with Sneva (1972) that sagebrush will return even when managed for minimal ecological impact. Chemical sagebrush control is a long lasting but not permanent range improvement practice. 


\section{ACKNOWLEDGMENTS}

We thank former graduate students John Balliette, Lynn Loomis, David Anderson, Hal Gordon, and Larry Brence, who conducted big sagebrushrelated research as thesis and dissertation topics and contributed to the long-term data collection effort required for this paper. We also thank many other students who assisted with periodic data collection. We thank the Farmington and Albuquerque Bureau of Land Management district offices for their help in this research. John Vallahos and Steve Hinckey with the Bureau of Land Management helped established the research sites, and Sterling White provided ongoing assistance.

\section{LITERATURE CITED}

Bartlett, E. T., and D. R. Betters [eds.]. 1983. Overstory-understory relationships in western forests. Colorado State Agr. Exp. Sta., West. Regional Res. Pub. 1. Fort Collins, $\mathrm{CO}$.

Bartolome, J. W., and H. F. Heady. 1978. Ages of big sagebrush following brush control. Journal of Range Management 31:403-406.

Baxter, G. 1998. Thinning dense sagebrush stands with Spike 20P. Rangelands 20:14-16.

BleAK, A. T., AND W. G. MIller. 1955. Sagebrush seedling production as related to the time of mechanical eradication. Journal of Range Management 8:66-69.

Bonham, C. D. 1989. Measurements for terrestrial vegetation. New York, NY: John Wiley and Sons. 338 p.

Bork, E. W., T. Thomas, and B. McDougall. 2001. Herbage response to precipitation in central Alberta boreal grasslands. Journal of Range Management 54:243-248.

Canfield, R. H. 1941. Application of the line interception method of sampling range vegetation. Journal of Forestry 39:388-394.

FFolliot, P. F., and W. P. Clary. 1972. A selected and annotated bibliography of understory-overstory vegetation relationships. Univ. Ariz. Agr. Exp. Sta. Tech. Bull. 198. Tucson, AZ.

Freund, R. J., And R. C. Littell. 2000. SAS system for regression. 3rd ed. Cary, NC: SAS Institute, Inc. 254 p.

Frischinecht, N. C., and A. P. Plummer. 1955. A comparison of seeded grasses under grazing and protection on a mountain brush burn. Journal of Range Management 8:170-175.

GreENE, W. H. 2003. Econometric analysis. 5th ed. Upper Saddle River, NJ: Prentice Hall. 1026 p.

HaRNISS, R. O., AND R. B. MuRRAY. 1973. 30 years of vegetal change following burning of sagebrush-grass range. Journal of Range Management 26:322-325.

Hedrick, D. W., D. N. Snyder, F. A. Sneva, and C. E. Poulton. 1966. Ecological response of sagebrush-grass range in central Oregon to mechanical and chemical control of Artemisia. Ecology 47:432-439.

JAMESON, D. A. 1967. The relationship of tree overstory and herbaceous vegetation. Journal of Range Management 20:247-249.
Johnson, J. R., and G. F. Payne. 1968. Sagebrush reinvasion as affected by some environmental influences. Journal of Range Management 21:209-213.

Johnson, W. M. 1969. Life expectancy of sagebrush control in central Wyoming. Journal of Range Management 22:177-182.

Maier, A. M., B. L. Perryman, R. A. Olson, and A. L. Hild. 2001. Climatic influences on recruitment of 3 subspecies of Artemisia tridentata. Journal of Range Management 54:699-703.

Masters, R. A., AND R. L. Sheley. 2001. Invited synthesis paper: principles and practices for managing rangeland invasive plants. Journal of Range Management 54:502-517.

McDaniel, K. C., D. L. Anderson, and L. A. Torell. 1992. Vegetation change following big sagebrush control with tebuthiuron. New Mex. State Univ. Agr. Exp. Sta. Bull. 764. Las Cruces, NM.

McDaniel, K. C., and J. F. Balliette. 1986. Control of big sagebrush (Artemisia tridentata) with pelleted tebuthiuron. Weed Science 34:276-280.

McDaniel, K. C., L. A. Torell, and J. W. Bain. 1993. Overstory-understory relationships for broom snakeweed-blue grama grasslands. Journal of Range Management 46:506-511.

SchmisseuR, E., AND R. Miller. 1980. Economics of spraying big sagebrush communities of eastern Oregon. Ore. State Univ. Circular 686, Corvallis, OR.

Scrifres, C. J. 1980. Brush management. College Station, TX: Texas A\&M University Press. $360 p$.

Scrifres, C. J., J. L. Mutz, R. E. Whitson, and D. L. Drawe. 1982. Interrelationships of huisache canopy cover with range forage on the coastal prairie. Journal of Range Management 35:558-562.

Sneva, F. A. 1972. Grazing return following sagebrush control in eastern Oregon. Journal of Range Management 25:174-178.

StURGES, D. L. 1993. Soil-water and vegetation dynamics through 20 years after sagebrush control. Journal of Range Management 46:161-169.

Thilenius, J. F., AND G. R. Brown. 1974. Long-term effects of chemical control of big sagebrush. Journal of Range Management 27:223-224.

Torell, L. A., K. C. McDaniel, and C. G. OchoA. 2005. Economics and optimal frequency of Wyoming big sagebrush control with tebuthiuron. Rangeland Ecology and Management 58:77-84.

Wambolt, C. L., K. S. Walhof, and M. R. Frisina. 2001. Recovery of big sagebrush communities after burning in south-western Montana. Journal of Environmental Management 61:243-252.

WatTS, M. J., AND C. L. WamboLt. 1996. Long-term recovery of Wyoming big sagebrush after four treatments. Journal of Environmental Management 46:95-102.

Weldon, L. W., D. W. Bohmont, and H. P. Alley. 1958. Re-establishment of sagebrush following chemical control. Weeds 6:298-303.

Wright, H. A., and A. W. Bailey. 1982. Fire ecology, United States and southern Canada. New York, NY: John Wiley and Sons. $501 \mathrm{p}$.

Young, J. A., AND R. A. Evans. 1989. Dispersal and germination of big sagebrush (Artemisia tridentata) seeds. Weed Science 37:201-206. 